geological data supporting this claim, exhibit definite primitive and simian characteristics.

The reason for this would appear to be the belief that man is evolved from an anthropoid stock and, in consequence, any really ancient human bones would show evidence of this ancestry. Various fossil remains of man do, of course, exhibit such characteristics, but there are others which do not, and the question arises as to whether Homo sapiens has evolved to his present state via the anthropoids. Upon this important matter I am not entitled to express an opinion, but from my archæological researches, $I$ am compelled to believe that intelligent beings - shall we call them-were in existence certainly a long way back in Pliocene time, and probably in that of the Upper Miocene.

As things stand at present, however, I am confronted by the anatomists who tell me that no known anthropoid ape was sufficiently evolved at such epochs to make it possible for any flint-flaking being to have been in existence, and the impasse is complete. I have therefore read with great interest a remarkable article by Prof. H. H. Woollard, F.R.S., in the current number of Science Progress. In this article, Prof. Woollard suggests that man arose from the primitive primate stem in very remote times, and long prior to the branching off of the anthropoids. He states: "If man has avoided many of the anthropoid specialisations it is logical to expect that he might retain many of the early primitive characters which the great apes have modified or lost". He then, having enumerated the various anatomical features which modern man possesses, and shown that these are derived from the preanthropoid primate stem, continues: "Those who have these characters could not be derived from those who have lost them. A recrudescence of them by a subsequent mutation seems incredible".

Now it seems to me that these are very formidable arguments, not lightly to be put aside, and I should much like to know what other anatomists have got to say about them. If they are correct, then the great antiquity of the modern type of man, and of intelligent beings capable of implement making, becomes increasingly probable.

$$
\text { Hedges, }
$$

J. REID MOIR.

One House Lane,
Ipswich.
Sept. 18.

\section{Prof. Buckland and Oxford}

The verses which follow are printed by permission of Sir Edmund Phipps, K.C.B., who found them among the papers of his great-grandfather William Foskett of Bath (1763-1843), who was accustomed to preserve current songs, verses and anecdotes, communicated to him in various handwritings.

William Buckland (1784-1856) was one of the founders of scientific geology. He began to lecture at $O x f o r d$ in 1813, and a special readership in geology was founded for him in 1819. He was elected fellow of the Royal Society in 1818, president of the Geological Society of London in 1824 and 1840 , president of the British Association at Oxford in 1832, and Dean of Westminster in 1845. His best-known work, "Reliquiae Diluvianae", was published in 1823; his Bridgewater Treatise on "Geology and Mineralogy" in 1836 .

13 Canterbury Road, John L. MYres. Oxford.
An Intended Epitaph on P[Rofessor] Buckland AT OXFORD

Mourn, Ammonites, mourn, o'er his funeral urn, Whose neck ye must grace no more.

Gniss, Granite, and Slate, he settled your date, And his, ye must now deplore.

Weep, caverns, weep, with filtering drip, Your recesses he'll cease to explore,

For mineral veins and organic remains No stratum again will he bore.

Oh, his wit shone like chrystal ! his knowledge proFrom Granite and Gravel descended,

No trap could deceive him, no slip $c^{d}$-confound Nor specimen true or pretended.-

He knew the birth place of each pebble so round, And how far its tour had extended.-

Though eloquence roll'd, like the deluge retiring In which many carcases floated,

To a subject obscure he gave charms so inspiring Young and old on geology doted.

He stood like an out-lier, his hearers admiring In pencil each anecdote noted.

Where shall we our great Professor inter

That in peace may rest his bones?

If we hew him a rocky sepulchre

He'll rise to break the stones

And examine each stratum that lies around,

For he's quite in his element under ground.-

If with mattock and spade his body we lay

In the common alluvial soil

He'll start and snatch those tools away

Of his own geological toil.

In a stratum so young the Professor disclaims

That imbedded $\operatorname{sh}^{d}$ lie his organic remains.

Then exposed to the drip of some case-hardening His carcase let Stalactite cover,

And to Oxford the petrified Sage let us bring

When he is incrusted all over.

There with mammoths and crocodiles high on a shelf Let him stand as a monument raised to himself.

\section{Annual Cycle of Responsivity of Castrated Albino Mice to Estrone Injection}

LAQUEUR, at the sixteenth International Congress of Physiologists held at Zurich in August last, reported that the response given by capons to a given dose of androgen varies according to the time of year, being lowest in winter and highest in summer. An analogous rhythm in the responsivity of castrated albino mice to monthly injections of 1 I.U. of cestrone has been found to exist, the response being more than three times as great in May as in November. The upper full-line curve in the accompanying figure represents the response given according to the State Hygiene Institute's method of evaluating vaginal smear tests in a group of 60 mice. In this method (not yet published), points are awarded to each smear (cornified epithelial cells only 5, sporadic nucleated cells 4, cornified and nucleated cells in approximately equal number 3 , sporadic cornified cells 2, nucleated cells only $\mathrm{I}$, and absence of epithelial cells 0 points); maximum response in a group of 20 mice is thus 100 points. The lower curve represents 